\title{
Chemoprophylaxis of Amoebiasis with Entamide Furoate*
}

\author{
M. P. SIVASANKRAN, M.B., B.S. ; P. S. GUPTA, M.D., ; R. K. SANYAL, M.D., Ph.D. \\ H. K. CHUTTANI, M.D., D.T.M.
}

Brit. med. F., 1966, 1, 839-840

A large section of the world's population suffers from amoebiasis and a still larger number of people harbour the parasite in their intestines. Though effective remedies for amoebiasis have been established, the number of cases of infection and relapses continues to be high.

Prolonged use of anti-amoebic agents for the prevention of amoebic infection has been recommended (Craig, 1940). Since the spread of infection is possible even under the best hygienic conditions, widespread drug prophylaxis is impossible and scarcely justifiable. A better approach is to use this method for individuals exposed to situations where chances of infection are high. It may be a useful method in dealing with amoebiasis among the mentally deranged in a mental hospital, because they show a very high incidence of parasitic infestation (Birnkrant et al., 1945; Dubey et al., 1965). Prevention of amoebiasis among food handlers, especially of a large institution, is also necessary.

The first drug used for prophylaxis of amoebiasis was 5-7 di-iodo-8-hydroxyquinoline (Diodoquin). Later on other drugs like bismuth glycollylarsanilate (Milibis), 4-diethylamino-1-methylbutylaminoquinoline (Aralen), and stilomycin (Puromycin) were used by various workers (Craig, 1940; Hoekenga, 1952 ; Berberian et al., 1952 ; Young and Freed, 1958).

These drugs are known to have toxicities and as such cannot be advocated for long-term prophylaxis. In view of the encouraging results of entamide furoate in the treatment of amoebiasis (Woodruff and Bell, 1960 ; Marsden, 1960 ; Dubey et al., 1965) it was decided to explore the utility of this drug as a chemoprophylactic agent. A combination of entamide furoate, streptomycin sulphate, and chloroquine phosphate was also tried in another group of patients. This was done in order to assess the influence of bacterial suppression by streptomycin on the control of Entamoeba histolytica infection. A small dose of chloroquine was included to find out its value in prevention of hepatic involvement in cases of intestinal amoebiasis. The trial was conducted in an institutionalized group in which the risk of fresh infection and reinfection was high, because of close contact, lack of personal hygiene, and high incidence of amoebiasis.

\section{Material and Methodology}

One hundred and eighty-six inmates of the Mental Hospital in Delhi constituted the material for the study. These subjects were clinically examined and specimens of their stools, freshly passed, were tested on two consecutive days before the institution of the trial. Saline and iodine-stained stool smears were examined. The inmates were placed in three groups by the method of random sampling. Those who were unmanageable on account of their mental state were dropped from the study. The subjects that remained were assigned a code number and further references to them or to their stool specimens were made by using these numbers. In Group I 70 subjects received daily one tablet containing $500 \mathrm{mg}$. entamide furoate. In * From the Gastroenterology Unit, Department of Medicine, Maulana
Azad Medical College. New Delhi.
Group II 56 inmates received daily one tablet containing 250 $\mathrm{mg}$. entamide furoate, $150 \mathrm{mg}$. streptomycin sulphate, and 50 mg. chloroquine phosphate (compound tablet). In Group III 60 inmates were given a placebo tablet containing $165 \mathrm{mg}$. starch, $5 \mathrm{mg}$. magnesium stearate, and $450 \mathrm{mg}$. lactose. Thus a double-blind controlled trial was organized to obviate the chances of error inherent in such clinical trials.

Of the 186 subjects $57 \%$ were male and $43 \%$ were female, and their ages ranged from 13 to 72 years.

The study extended from December 1963 to May 1964, and the drugs were administered daily for a period of four months. During this period bi-weekly examinations of the patients were carried out for clinical assessment and drug reactions. At the end of the trial the clinical examination was repeated and the stool specimens were re-examined.

\section{Results and Comments}

On initial survey 35 inmates of the Mental Hospital were found to be positive for amoebic infection, thus giving an overall incidence of $18.6 \%$. Almost a similar incidence of infection was found in the three groups (Table I).

TABLE I.-Results of Chemoprophylaxis in Intestinal Amoebiasis

\begin{tabular}{|c|c|c|c|c|c|c|c|c|c|}
\hline \multirow[b]{2}{*}{ Group : } & \multicolumn{3}{|c|}{$\begin{array}{c}\text { No. of Patients } \\
\text { in } \\
\text { Each Group }\end{array}$} & \multicolumn{3}{|c|}{$\begin{array}{c}\text { No. of Patients } \\
\text { with Cyst and/or } \\
\text { Trophozoites }\end{array}$} & \multicolumn{3}{|c|}{$\begin{array}{c}\text { Incidence } \\
\text { of Amoebic } \\
\text { Infection }\end{array}$} \\
\hline & I & II & III & I & II & III & I & II & III \\
\hline $\begin{array}{ll}\text { Before trial } & \\
\text { After } \Rightarrow\end{array}$ & $\begin{array}{l}70 \\
70\end{array}$ & $\begin{array}{l}56 \\
56\end{array}$ & $\begin{array}{l}60 \\
59 *\end{array}$ & $\begin{array}{r}12 \\
0\end{array}$ & 11 & $\begin{array}{l}12 \\
19\end{array}$ & $\begin{array}{c}(\%) \\
17 \cdot 1 \\
0\end{array}$ & $\begin{array}{r}(\%) \\
19 \cdot 6 \\
1.8\end{array}$ & $\begin{array}{l}(\%) \\
20 \cdot 0 \\
32 \cdot 2\end{array}$ \\
\hline
\end{tabular}

- One patient in Group III died of acute myocardial infarction.

In Group I, which received $500 \mathrm{mg}$. of entamide furoate, the incidence of amoebiasis was reduced to nil from an initial incidence of $17.1 \%$. These results were found to be statistically significant $(P=0.01)$. This shows that in the dosage employed the drug was effective in clearing the stools of the parasite and in preventing reinfection as well. Comparison of these results with those of Group III show that the incidence of amoebiasis in the control group had increased from the initial $20 \%$ to $32.2 \%$. This increase in cases of amoebiasis may be due either to reinfection or failure to detect them on the preliminary stool examination.

In Group II, which received a compound tablet containing entamide furoate, streptomycin sulphate, and chloroquine phosphate, the incidence of amoebiasis came down from an initial $19.6 \%$ to $1.8 \%$. These results were also found to be statistically significant ( $P$ value between 0.05 and 0.021 ).

The data indicate that the daily administration of entamide furoate alone and of the compound tablet in the dosage mentioned were effective not only in preventing fresh infection but also in suppressing the existing amoebic infection. Entamide furoate in dosage of $500 \mathrm{mg}$. was, however, a little superior to the compound tablet, and this is probably because the content of entamide furoate given in the form of a compound tablet to Group II was only half of that given to Group I. Thus it seems that the addition of streptomycin 
in the given dosage did not change the bacterial flora in such a manner as to reduce the required dosage of entamide furoate.

\section{Clinical Assessment}

Dysentery or diarrhoea did not occur among subjects in Group I throughout the period of the trial. In Group II, however, one person developed acute dysentery when the stools were positive for trophozoites of Entamoeba histolytica, and two developed diarrhoea, one of whom had Entamoeba histolytica cysts on examination of the stools. In the control group three persons developed acute dysentery where trophozoites of Entamoeba histolytica were detected and eight got diarrhoea. In seven of these eight cysts and/or trophozoites of Entamoeba histolytica were demonstrated in the stools (Table II).

TABLE II.-Clinical Assessment of Chemoprophylaxis in Amoebiasis

\begin{tabular}{|c|c|c|c|c|c|c|c|c|c|c|c|c|}
\hline \multirow[b]{2}{*}{ Groups: } & \multicolumn{3}{|c|}{$\begin{array}{l}\text { No. of Patients } \\
\text { with Acute } \\
\text { Dysentery and } \\
\text { Trophozoites } \\
\text { in Stools }\end{array}$} & \multicolumn{3}{|c|}{$\begin{array}{l}\text { No. of Patients } \\
\text { with Diarrhoea } \\
\text { and Cysts and/ } \\
\text { or Trophozoites } \\
\text { in Stools }\end{array}$} & \multicolumn{3}{|c|}{$\begin{array}{l}\text { No. of Patients } \\
\text { with Diarrhoea } \\
\text { and Stools } \\
\text { Negative for } \\
E \text {. histobytica }\end{array}$} & \multicolumn{3}{|c|}{$\begin{array}{l}\text { No. of } \\
\text { Patients with } \\
\text { Enlarged } \\
\text { and } \\
\text { Tender Liver }\end{array}$} \\
\hline & I & II & III & I & II & III & $\mathbf{I}$ & II & III & I & II & InI \\
\hline $\begin{array}{r}\text { Before } \\
\text { trial }\end{array}$ & 0 & 0 & 0 & 0 & 1 & 1 & 0 & 0 & 1 & 3 & 2 & 1 \\
\hline $\begin{array}{c}\text { After } \\
\text { trial }\end{array}$ & 0 & 1 & 3 & 0 & 1 & 7 & 0 & 1 & 1 & 3* & 0 & 1 \\
\hline
\end{tabular}

- One patient in Group I developed amoebic liver abscess, which had to be treated with emetine and aspiration of abscess.

A significantly enlarged tender liver was found in six subjects on initial survey. Four were positive for Entamoeba histolytica infection on stool examination. In others the clinical picture simulated amoebic hepatitis but stool examination was negative. There were three of these cases in Group I, two in Group II, and one in Group III.

The enlarged liver regressed in both the cases in Group II, but in the four cases of Group I and III there was no effect on hepatic enlargement ; actually one case in Group I developed amoebic liver abscess, which had to be treated with emetine and aspiration (Table II). The number of cases with hepatic involvement was too small to enable conclusions to be drawn about the utility of these drugs in the prevention of hepatic complications. It is quite possible that one of the cases in Group I had already developed liver abscess before the begining of the trial, and this may account for the patient who developed an overt liver abscess in that group.

\section{Drug Reactions}

The side-effects of the drugs, such as flatulence, distension of abdomen, nausea, vomiting, pruritus, and urticaria, were observed in 12 cases $(17.1 \%)$ in Group $I$ and in $10(17.0 \%)$ in Group II. Quite often there was more than one sidereaction in the same subject (Table III). These side-effects were not severe enough to warrant discontinuing the drugs.
TABLE III.-Side-effects of Drugs Used for Chemoprophylaxis of Amoebiasis

\begin{tabular}{|c|c|c|c|c|c|c|}
\hline & \multicolumn{2}{|c|}{ Group I } & \multicolumn{2}{|c|}{ Group II } & \multicolumn{2}{|c|}{ Group III } \\
\hline & $\begin{array}{l}\text { No. of } \\
\text { Cases }\end{array}$ & $\begin{array}{c}\text { Per- } \\
\text { centage }\end{array}$ & $\begin{array}{l}\text { No. of } \\
\text { Cases }\end{array}$ & $\begin{array}{c}\text { Per- } \\
\text { centage }\end{array}$ & $\begin{array}{l}\text { No. of } \\
\text { Cases }\end{array}$ & $\begin{array}{c}\text { Per- } \\
\text { centage }\end{array}$ \\
\hline $\begin{array}{lcc}\text { Flatulence } & & \\
\text { Distension of abdomen } \\
\text { Nausea, vomiting } & \ldots \\
\text { Pruritus } & \ldots & \ldots \\
\text { Urticaria } & \ldots & \ldots\end{array}$ & $\begin{array}{r}12 \\
7 \\
0 \\
1 \\
0\end{array}$ & $\begin{array}{c}17 \cdot 1 \\
10 \cdot 0 \\
0 \\
1 \cdot 4 \\
0\end{array}$ & $\begin{array}{l}6 \\
6 \\
6 \\
2 \\
2\end{array}$ & $\begin{array}{r}10 \cdot 7 \\
10 \cdot 7 \\
10 \cdot 7 \\
3 \cdot 6 \\
3.6\end{array}$ & $\begin{array}{l}0 \\
1 \\
0 \\
0 \\
0\end{array}$ & $\begin{array}{l}0 \\
1 \cdot 6 \\
0 \\
0 \\
0\end{array}$ \\
\hline
\end{tabular}

\section{Summary and Conclusions}

A clinical trial of entamide furoate and of a combination of entamide furoate, streptomycin sulphate, and chloroquine phosphate was carried out to evaluate their efficacy as chemoprophylactic agents in amoebiasis.

One hundred and eighty-six inmates of the Mental Hospital in Delhi, with an overall initial incidence of amoebic infection of $18.6 \%$, constituted the material for the study. These subjects were randomly divided into groups, and a double-blind controlled study was instituted. The drugs were administered daily for a period of four months.

The results showed that entamide furoate alone in dosage of $500 \mathrm{mg}$. daily was more effective than the combination of $250 \mathrm{mg}$. entamide furoate, $150 \mathrm{mg}$. of streptomycin sulphate, and $50 \mathrm{mg}$. chloroquine phosphate for prophylaxis against amoebiasis. The relative efficacy of these drugs in the prevention of hepatic amoebiasis was difficult to determine, because of the small number of cases with liver involvement in this experiment.

The side-effects of the drugs were not severe enough to warrant discontinuing them.

We are grateful to Dr. A. S. Sen, Superintendent of Medical Services, Delhi, for permitting us to carry out the study in the Mental Hospital, and to the Principal, Maulana Azid Medical College, New Delhi, for permission to publish the data. We are deeply indebted to Dr. S. B. Mathur, Psychiatrist in the Mental Hospital, Delhi, for help in the execution of the study, and to Messrs. Boots Pure Drug Company Ltd., Nottingham, England, for providing the drugs and a liberal grant to enable us to carry out the trial.

\section{REFERENCES}

Berberian, D. A., Dennis, E. W., Korns, R. F., and Angelo, C. A. (1952). 7. Amer. med. Ass., 148, 700 .

Birnkrant, W. B., Greenberg, M., and Most, H. (1945). Amer. F. publ. Hlth, 35, 805 .

Craig, C. F. (1940). Amer. F. trop. Med., 20, 799.

Dubey, M. P., Gupta. P. S., and Chuttani, H. K. (1965). F. trop. Med. Hyg., 68, 63. (1965). Ibid., 68, 153.

Hoekenga, M. T. (1952). F. Lab. clin. Med., 39, 267.

Marsden, P. D. (1960). Trans, roy. Soc. trop. Med. Hyg., 54, 396.

Woodruff, A. W., and Bell, S. (1960). Ibid., 54, 389.

Young, M. D., and Freed, J. E. (1957). Amer. 7. trop. Med., 6, 808. 